\author{
COREY L. WILLIAMS
}

\title{
Chrislam, Accommodation, and the Politics of Religious Bricolage in Nigeria
}

\begin{abstract}
This article provides an ethnographic exploration of a new religious movement in Nigeria that often goes by the name 'Chrislam'. With a particular focus on the Ogbomoso Society of Chrislam, the article documents the group's origins and practices, as well as its public reception. Founded on a claimed vision from God in 2005, the group teaches that Christianity, Islam, and African Indigenous Religions come from the same source and should be reunited into a single religious movement. Core to their understanding is what they call 'a spirit of accommodation', which provides a divine directive to exceed mere tolerance or coexistence and combine these religions under one roof. With their mission of pursuing unity and commonality while dispelling differences, the group manages to creatively embed multiple complex religious traditions into their belief structures, liturgical practices, and ritual ceremonies, in what can be described as a religious bricolage. Despite the group's intention to promote peace and unity, and act as a counterpoint to violent movements such as Boko Haram, the Ogbomoso Society of Chrislam finds itself at the centre of an on-going debate about the politics of religious bricolage and the resulting cultural limits of acceptable forms of religious entanglements.
\end{abstract}

Key Words: Chrislam, Nigeria, Accommodation, Bricolage, Christianity, Islam, African Indigenous Religions

\section{INTRODUCTION}

If the term 'Chrislam' sounds like something out of a science fiction novel, perhaps it is because linguistically that is where it originates. The first usage of the term can be traced to G.K. Chesterton's 1914 novel, The Flying Inn. Set in dystopian, futuristic England, a progressive form of Islam, sprinkled with remnants of Christianity 
dominates the social and political life of the nation. One of the characters, an Irishman named Patrick Dalroy, concerned and discussing this state of affairs, wittily coins the portmanteau word, 'Chrislam'. As Chesterton put it in the novel: '... the time had come for a full unity between Christianity and Islam'. 'Something called Chrislam perhaps', said the Irishman, with a moody eye'. ${ }^{1}$ A similar reference is also found in Arthur C. Clarke's 1992 short story, 'The Hammer of God: A New Story'. ${ }^{2}$ In this fictitious, end times narrative, a super religion known as Chrislam emerges as a result of the US's involvement in the Gulf Region. As Clarke put it in his story: 'The time had been ripe for a new religion embodying, as even its severest critics admitted, the best elements of two ancient ones ... Chrislam had grown explosively, though it was still far outnumbered by its parent religions [Christianity and Islam]'. ${ }^{3}$

Beyond this world of science fiction, however, it is in Nigeria where Chrislam has been taken from neologism to the formation of a real-world new religious movement. This article focuses on a recent iteration of the movement known as the Ogbomoso Society of Chrislam (OSC), but antecedent groups date back at least to the 1950s. While the form and content varies across the movement, each group has intentionally fused elements from Christianity and Islam, with African Indigenous Religions (AIR) also being combined in some groups. ${ }^{4}$ The article offers a brief history of Chrislam in Nigeria before shifting attention to an ethnographic exploration of the origins, practices, and public reception of OSC. ${ }^{5}$

\section{CHRISLAM: A BRIEF HISTORY}

It was Bishop Stephen Neill, the Scottish missionary and scholar, who first documented a Chrislam-esque group in Nigeria. During his grand 1950 tour and evaluation of theological education in Africa, Neill made a stop in Benin City. According to his travel diary, he encountered a group that '... contained elements from Christianity, from Islam, and from pagan traditions. ${ }^{6}$ The group was initiated by Oba Aken-zua II, who was the King of Benin from 1933-1978. As Neill notes, Akenzua II was officially 'a Christian and an Anglican ... but some years ago he decided to start a religion of his own'. ${ }^{7}$ While Neill notes that the group experienced some popularity, he was informed that, '... it has dwindled and no one takes any interest in it any more'. ${ }^{8}$ Whatever the case, Neill toured the building that Aken-zua II was in the process of constructing for the group. While there is no definitive link, this group is very likely within the heritage of the Holy Aruosa Cathedral, which still exists in Benin today. ${ }^{9}$ Today, the Holy Aruosa Cathedral is led by Aken-zua II's son, the Oba of Benin, His Royal Majesty Omo n'Oba n'Edo Uku Akpolokpolo Erediauwa I, and the group continues to combine elements of Christianity, Islam, and AIR.

The first group to go by the name Chrislam cropped up in Lagos, Nigeria in 1976. ${ }^{10}$ It was founded and continues to be led by Holy Royal Highness Tela Tella. Tella claims that he received a divine revelation in which he was commissioned to start a religious group called Ifeoluwa: The Will of God Mission. The name Ifeoluwa is a Yoruba word, meaning 'God's love'. As Tella recalls, Ifeoluwa was established to bridge the divide between Nigeria's religious traditions by incorporating elements of 
Christianity, Islam, and AIR. While Ifeoluwa is the official name, Tella and group members often refer to their group as Chrislam. Members of Ifeoluwa revere Tella as the Living Messiah and he claims to continue to receive divine revelations. He is currently writing the Ifeoluwa Book - said to be the final book of revelation from God. Despite its decades-long presence in Lagos, the group has remained relatively small with less than 100 regular members. Scholars Marloes Janson and Mustapha Bello believe this may be due in part to the strict regulations imposed on members. ${ }^{11}$ Yet, Hazzan-Odede Adeboye, the group's new crusader, believes they will expand significantly in the coming years. ${ }^{12}$

The origins of another Chrislam group, also launched in Lagos, can be traced to the late 1980s. It was founded and continues to be led by Prophet Dr SamusideenOladimeji Saka. ${ }^{13}$ While performing the Hajj in 1989, Saka claims to have received a divine revelation. As Kehinde Emmanuel Obasola, in his important research on the group, relates, Saka '... dreamt that he received the mandate to pioneer a religious movement that will bring both Christians and Muslims to worship together in the same place without any inhibition'. ${ }^{14}$ Based on this revelation, Saka founded the Chrislamherb World Faith Mission in 1990. ${ }^{15}$ The term Chrislamherb denotes a synthesis of Christianity, Islam, and herbalism. Despite the inclusion of herbalism, however, Saka maintains that the group has never practiced AIR fully. ${ }^{16}$ In 1996, Saka received further divine inspiration, after which he dropped his career in AIR medicine and herbalism. ${ }^{17}$ Subsequently, the group's name was changed to Oke Tude, a Yoruba phrase meaning 'Mountain of Loosing Bondage'. ${ }^{18}$ The minimal existent literature on Oke Tude reveals a movement defined by its deliverance ministry. ${ }^{19}$ In particular, Saka claims to be able to free women from the bondage of barrenness. $\mathrm{He}$ also '... claims that he has the ability to catch and arrest those operating with the spirit of witchcraft and that members of Oke Tude are immuned [sic] from the activities of these malevolent forces' ${ }^{20}$ The group is mostly female, uneducated, poor, and around 80 percent are from a Muslim background. ${ }^{21}$ While capturing motivations is always tenuous, many join the group for healing, economic improvement, spiritual improvement, social mobility, and access to education. Given these motivations and considering the group's charismatic style of worship, Janson and Bello classify this group within Islamic Pentecostalism. In terms of numbers, several reports indicate Oke Tude is around 1500 strong, with domestic branches in Lagos, Ibadan, and Abuja, as well as an international branch in London, UK. However, in Obasola's research, the group claims to have around 15,000 members spread all throughout southwest Nigeria in the states of Lagos, Ogun, Oyo, and Osun. ${ }^{22}$

\section{THE OGBOMOSO SOCIETY OF CHRISLAM (OSC)}

Founded in 2005 in Ogbomoso, Nigeria, OSC is the most recent iteration of the Chrislam movement. As of 2018, OSC boasts an active membership of approximately 300 members and an attendance directory of over 1200 people. ${ }^{23}$ The basic demographic structure of the group is illustrated in the chart below and is based on a survey conducted in July $2018 .{ }^{24}$ First, the membership is over 60 per cent male. Yet, 
despite having a slight male majority, the female membership is very active and involved in the organisation of OSC. In the area, Christian churches tend to have a dominant female membership - in many cases this can be 60-70 per cent of a church. Males, however, dominate attendance at local mosques. AIR ritual sites and festivals typically have an even mix of males and females, although this is often difficult to track. In terms of age, just over 80 per cent are under the age of 35. This dominance by the youth population is unsurprising, considering that over 70 per cent of Nigeria's population is under the age of 35. Indeed, according to recent estimates from the United Nations, 44.4 per cent is aged $0-14$, while only 4.5 per cent reach the age of $60 .{ }^{25}$ Interestingly, around 70 per cent of OSC members are either in university or have a university degree. Compared to the surrounding population, OSC is a highly educated group. For Oyo State as a whole, as of 2009, only 7.6 per cent of the population had completed a post-secondary degree programme. ${ }^{26}$ Relatedly, the living standards of OSC members are on average much higher than the rest of the Ogbomoso population with around 75 per cent claiming a moderate standard of living. A recent government survey for the whole of Ogbomoso places under 50 per cent in this category. ${ }^{27}$ In terms of ethnicity, the Yoruba dominate with 90 per cent of the group claiming this heritage. Other ethnicities represented were Igbo (6 per cent), Hausa-Fulani ( 2 per cent), and the remaining split between Ijaw, Ogoni, and Berom. Lastly, prior to coming to OSC, most members claim to have been primarily affiliated with a single religious tradition. For instance, around half of OSC's members were primarily affiliated with a Christian tradition before becoming members of OSC. However, since joining OSC, nearly all members ( 95 per cent) claim to belong to multiple religious groups.

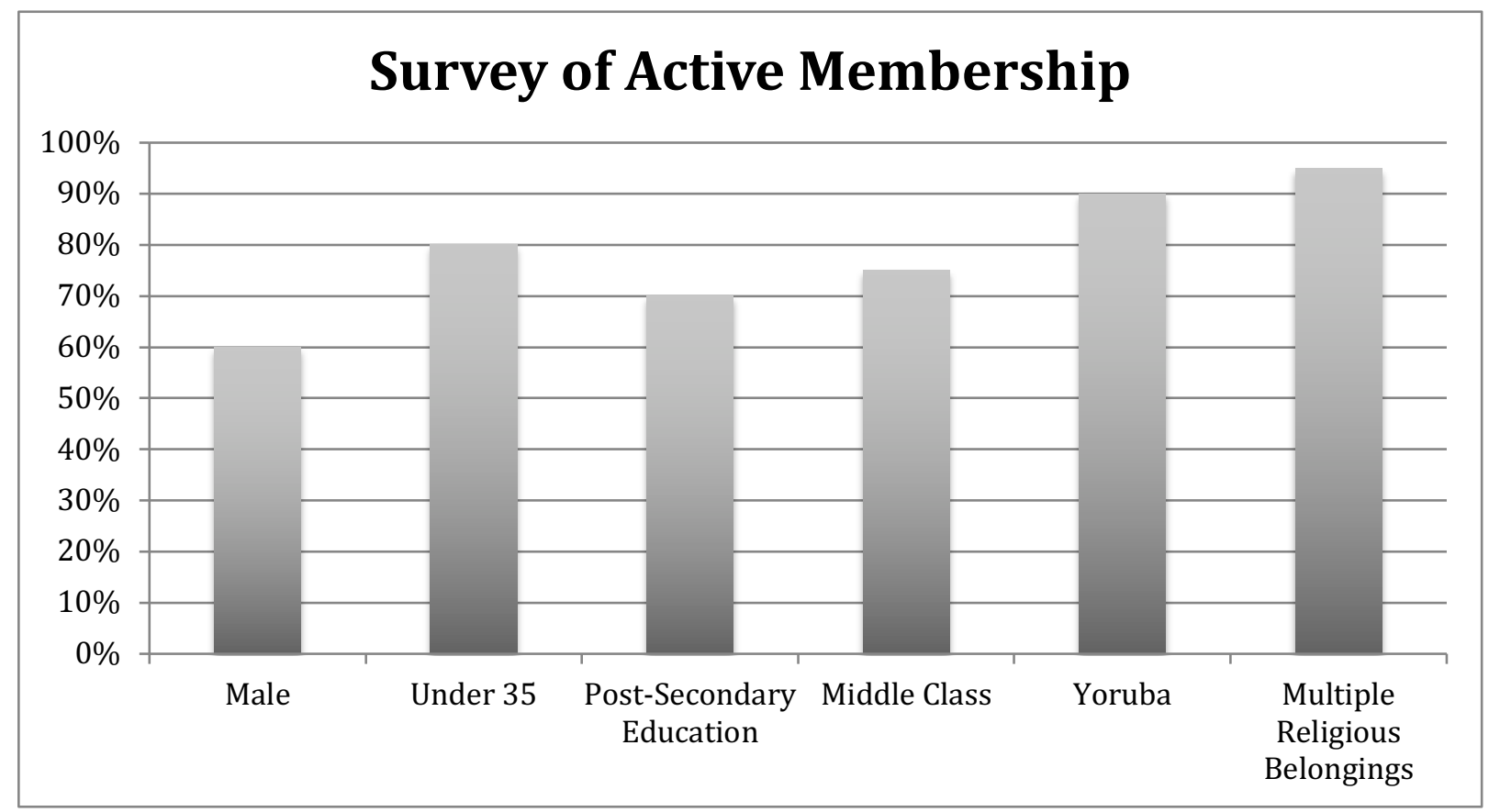




\section{THE ORIGINS AND MISSION OF OSC}

Information related to the origins of OSC is limited to testimonies made by the five self-proclaimed co-founders of the group: Ibukunoluwa, Tantoluwa, Ayokunle, Olumide, and Obáfẹmi. ${ }^{28}$ Similar to Ifeoluwa and Oke Tude, the founders of OSC claim to have received a divine revelation from God to start a religious community dedicated to promoting unity and commonality between adherents of Christianity, Islam, and AIR. As Ọbáfẹmi recounted to me in an interview, 'We did not know each other when all of this started. We were strangers ... God introduced us, you see, for this purpose. ${ }^{29}$ In particular, the founders believe God selected them due to their divergent religious backgrounds and networks. Prior to OSC, Ibukunoluwa primarily identified as Catholic, Tantoluwa as Pentecostal, Ayokunle as Muslim, Olumide as Ahmadiyya, and Ọbáfẹmi as an Ifá worshipper. Thus, in terms of these primary religious identities, two of the founders came from a Christian background, two from a Muslim background, and one from an AIR background. According to Ibukunoluwa, 'This diversity of backgrounds allows our group to act as contact points with the various religious communities in Ogbomoso ... these are bridges and help us understand each other better. ${ }^{30}$ Like most of those in OSC, the founders now identify with and belong to multiple religious communities.

While the details of the divine revelation claimed by the founders is a complex and extensive story, a critical component that set the foundation for OSC and continues to motivate its raison d'être is a vision that each of them claims to have received simultaneously on Saturday, 1 January 2005. They describe the vision as being like a film that showed the corruption and destructiveness of religions around the world. As the vision progressed, the focus then shifted to the religious landscape of Nigeria, with Christianity, Islam, and AIR all being exposed and rebuked. Christianity was symbolised as a landowner with great wealth that takes advantage of impoverished and uneducated people. Islam was symbolised as a warlord that divides his enemies, makes them submit, and teaches them to kill in the name of Allah. Finally, AIR were symbolised as a withered and dying tree that have lost their strength due to colonisation.

According to the founders, the vision continued with a twist on a popular Yoruba proverb. While there are many variations of the proverb, the original is commonly: Bi ewe ba pe l'ara ose, yio di ose (If the leaf stays long upon the soap, it will become soap). ${ }^{31}$ As J.D.Y. Peel has noted: 'This common proverb alludes to the fact that the soft black soap which was manufactured by the Yoruba from ash and palm oil was kept wrapped in leaves which would over time gradually dissolve into the soap itself. It is used to indicate how people will adapt to the circumstances they are placed in, gradually taking on the characteristics of a new environment'. ${ }^{32}$ While the explicit meaning sees the leaf turning into soap, the implicit meaning is that the soap assimilates elements of the leaf - a sort of mutual assimilation. In the vision, however, the proverb was adapted into the following form: 'As the leaf fell off the soap, nothing remained but a shell'. As Obáfẹmi explains: 'What we have here is an overhaul on an old proverb. We once thought these religions enhanced each other, 
improved each other. No, no, no. What has happened is not improvement. What has happened is [they have] been emptied of their substance ... their interaction has caused each to lose track of their common ground ... their common source'. ${ }^{33}$ Ayokunle offered further clarity: 'God has unblinded [sic] us. He revealed to us that religions in Nigeria have been corrupted by each other. Instead of enhancing each other, you see, the proverb reveals that the religions have become nothing but a shell'. ${ }^{34}$

After this revelatory exposé on how religion in Nigeria had become corrupt and destructive, the founders claim that God delivered a short monologue commanding them to 'work with and unite the religions of Nigeria' by founding OSC. As Obáfẹmi recalled, 'God told us that the same story has been told throughout history and in different religions if we would just listen ... Nigeria's religions come from the same source and it is now our job to accommodate them in a single community and reunite them as a single religion. ${ }^{35}$ In order to accomplish this, they were told to use the 'spirit of accommodation', a concept that has become central to OSC's mission and daily practice. To explain it, the co-founders often point to another popular Yoruba proverb:

The brash youth meets an ancient babalawo and strikes him. He meets an old herbalist and humiliates him. He runs into a venerable Muslim priest kneeling in prayer and knocks him to the ground. Ifa divined for such insolent ones who boasted that they were beyond correction. Is that so indeed? Don't you know that a youth who strikes a priest of Ifa will not partake of this world for long? Premature is the death of the youth who strikes the devout imam at his devotions. Speedily comes the death of maggots, speedily.

While the proverb may seem enigmatic to the uninitiated, OSC believes it provides a framework for how one should respond to and treat the 'Other'. In this case, despite Islam being a foreign religion, the imam is treated with the same respect and given the same space as the priest of Ifa. As members of OSC attest, this act of provision and the inevitable adjustment it implies goes beyond mere tolerance or coexistence. As one OSC member, Oluwaseun, puts it: 'Accommodation is not just about tolerating others ... If we only tolerate each other we are setting ourselves up for failure because we will grow tired of those we only tolerate ... even the sinners coexist and we are called to so much more'. ${ }^{36}$ Co-founder, Ibukunoluwa, adds to this:

The spirit of accommodation is about actively creating space and pursuing unity and commonality. This accommodation happens in [OSC's] religious services, yes, but it is also meant for everyday life ... It means becoming embedded and uniting with others instead of just tolerating them at a safe distance ... having this spirit is a gift from God because it tears down our walls of difference. It is also very radical because it does not resort to force, or demand reciprocity. ${ }^{37}$

While this concept of accommodation is complex, the notion of becoming embedded with the 'Other' is key to OSC's ethos of unity and dispelling differences. OSC 
teaches that it is not enough to just tolerate other religious communities at a distance; instead, by recognizing that Nigeria's religious traditions come from the same source, they believe it becomes possible to find common ground and reunite these traditions under one roof.

\section{THE ‘SPIRIT OF ACCOMMODATION’ IN PRACTICE}

One of the key ways that such accommodation plays out in the life of OSC is the way in which Christianity, Islam, and AIR are combined and embedded into the practices and ritual ceremonies of OSC's main service, known as the Tabernacle Gathering. In order not to infringe on the most sacred days for Muslims (Friday = Jumu'ah) or Christians (Sunday = Sabbath), OSC meets together on Saturday's. As well, OSC members are encouraged to keep their attachments with other religious communities and even form new attachments, so such an accommodation allows for this practice to flourish. As an example, one member, Olafunke, attends OSC's service on Saturday and a Redeemed Christian Church of God service on Sunday. Additionally, she visits an AIR diviner occasionally and performs the Islamic tradition of salat five times daily. ${ }^{38}$ Another member, Ishola, belongs to both a Sunni mosque and an Ahmadiyya mosque, takes part in AIR rituals, and frequently attends Pentecostal revivals - all while regularly attending OSC's Saturday service. ${ }^{39}$ These religious entanglements are a common feature among OSC's members.

Sermons at OSC feature pronouncements from the Bible, the Quran, and Yoruba proverbial literature and oral traditions (often from the Odu Ifá). In order to demonstrate parity, texts from multiple traditions are presented side-by-side. As an example, a November 2011 message on loving God gave the following pronouncements simultaneously:

Deuteronomy 6:5: 'And thou shalt love the Lord thy God with all thine heart, and with all thy soul, and with all thy might.'

Matthew 22:37: 'Thou shalt love the Lord thy God with all thy heart, and with all thy soul, and with all thy mind.'

Qur'ān, surah 3:31: 'If you love Allah then follow me, Allah will love you and forgive you of your sins.'

Yoruba Proverb: 'One does not trade with God and lose.'

Another sermon on truth from a July 2012 message provided the following pronouncements side by side:

Qur'ān surah 2:42: 'And mix not truth with falsehood, nor conceal the truth.'

John 8:32: 'And ye shall know the truth, and the truth shall make you free.' 
Psalm 85:11: 'Truth shall spring out of the earth; and righteousness shall look down from heaven.'

Yoruba Proverb: 'Truth arrives at the market and finds not a single buyer; however, lies are bought with ready cash.'

Within the context of a sermon from November 2011, the Qur'ān, Hadith, the New Testament, and a Yoruba proverb are used simultaneously to explain what many at OSC call the concept of 'One Love':

Love of God and neighbour is at the heart of all religious traditions. Qur'ān 3:31 speaks of this love of God, saying: 'If you love Allah then follow me, Allah will love you and forgive you of your sins.' Of loving one's neighbour, Muhammad said, 'None of you has faith until you love for your neighbour what you love for yourself.' In the Bible, in both the Old and New Testaments, this same trend continues. In Mark 12, it tells us to 'Love the Lord your God with all your heart, with all your soul, with all your mind, and with all your strength, and to love your neighbour as yourself.' These are given as the greatest commands, above all others ... In our Yoruba tradition, we say that, 'The person who gathers eggs to eat does not know that the chicken's orifice hurts.' This funny proverb teaches us to care for others. To show concern and love for more than ourselves ... The love that I speak of relates to all of the other truths. It is what brings it all together and provides a practical lens through which to live. If you want to know how to live, ask yourself, does this action or thought promote the love of God? Does it promote the love of others around me? It is this simple. ${ }^{40}$

Within the context of a sermon from July 2012, the Old Testament, the New Testament, the Qur'ān, and a reference to Yoruba cosmology are all presented to explain what many at OSC call the concept of 'One God':

We find the truth of One God everywhere ... We find this in the Old Testament. See for instance, Isaiah 44:6: 'Thus saith the Lord the King of Israel, and his redeemer the Lord of hosts; I am the first, and I am the last; and beside me there is no God.' One God. The same is in Christianity, in Mark 12:29, saying 'Hear, O Israel; The Lord our God is one Lord.' Again, One God ... this talk about the Trinity in Christianity has led many astray ... we find even Jesus saying in John 10:30 that, 'I and God are one.' In the Qur'ān, from 112:1: 'He is Allah, who is One.' Allah simply meaning 'God,' so God is one. Even in the Muslim confession of faith, the Shahada, we see that Muslims must confess that, 'There is no God but God' ... Finally, in our own [AIR] traditions, we have this same concept of one God, the creator God. In Yoruba cosmology, Olorun, or Olodumare, is the creator or sky God. There are many other powers below Olorun, but there is no doubt that God has unity and that Olorun is the same God mentioned in the above Scriptures ... We too have been endowed through our heritage with this wisdom. God has always been among us ... [we are] reclaiming this simplistic understanding of God across Christianity, Islam, and our own [AIR] traditions. ${ }^{41}$ 
As mentioned previously, this inclusion of multiple traditions is based on the belief at OSC that these traditions share a common source and should be reunited and practiced as a single religion. As one of the practitioners, Ositadimma, shared with me:

These monotheistic religions are of the same essence. What I mean by this, I will tell you. They are from the same source. They have the same qualities and characteristics. For instance, you look at our teachings and they are very similar ... love God and love people, really this is what it is. You look at our sacred traditions they are the same. It is the same story ... God's story ... Islam, Christianity, and traditional African religion are just different perspectives on the same story. And this means they are really the same religion that has been torn apart by the world. ${ }^{42}$

Given this belief that Christianity, Islam, and AIR come from the same source, OSC regularly calls upon prominent sources of authority from these traditions. For instance, the following quote is from a welcome address given by a member, Oluwaseun, at the beginning of a service in July 2012:

Hello. You are welcome. You are welcome to the Ogbomoso Society of Chrislam. I thank God you are here today. It is a beautiful day and I welcome you into the presence of God, the God of Abraham, Jesus, Muhammad, God of the Universe. Peace be upon us. You know, there is a Yoruba parable that says, 'Little by little is how the pig's nose enters the yard.' You see, we Nigerians have been led to be confused by religion for many years. Little by little, as the parable says, this has happened. Another parable from Igboland says 'If a habit lasts more than a year, it can turn into a tradition.' This confusion has become a tradition in our land ... the truth is, God's truth is that the religions of Nigeria are of the same essence ... Islam and Christianity, our traditional religious beliefs ... these are the same and that is what we celebrate today. We celebrate this understanding ... we people, we divide ourselves into factions ... God says we are one. It does not matter what tribe or family you come from, what your wealth or status in your community. You are welcome. You are part of one people. AMEN. ${ }^{43}$

The inclusion of 'the God of Abraham, Jesus, Muhammad, God of the Universe' is also used in the context of prayer, as can be seen from this prayer from a member, Olujimi, in a January 2012 service:

God, we humbly approach you today. The evidence of your glory and majesty is all around us ... Teach us to better love you, to better love those around us. We are willing, oh God of Abraham, of Jesus, of Muhammad, to be your servants. That is why we come together as one family. We come together to serve. We come together as proof that peoples of all nations and tongues, peoples of this background and that background, of this tribe and that tribe, even, oh almighty God, of different religions ... God, we know the truth, that you are the only God. There are not really different religions and we have corrupted your simplistic design. You want unity and peace, where we divide and conquer ... We ask for your forgiveness, oh God of Abraham and Jesus 
and Muhammad, you are the God of the Universe. Teach us to forgive each other. Teach us to love one another as you have loved us. Amen. ${ }^{44}$

Finally, the same can be witnessed in the original songs produced by OSC members, such as the following:

Holy, Holy, Holy, God of the Universe.

Holy, Holy, Holy, we come before You.

Holy, Holy, Holy, accept our worship.

You are merciful, you are gracious, Hallelujah!

Holy, Holy, Holy, God of Abraham.

Holy, Holy, Holy, You are One.

Holy, Holy, Holy, You are God.

You are worthy, you are all-powerful, Hallelujah!

Holy, Holy, Holy, God of Jesus.

Holy, Holy, Holy, we are One People.

Holy, Holy, Holy, give us peace.

Give us harmony, give us rest, Hallelujah!

Holy, Holy, Holy, God of Muhammad.

Holy, Holy, Holy, we have One Love.

Holy, Holy, Holy, loving You,

Loving all, loving freely, Hallelujah! ${ }^{45}$

Two ritual ceremonies are practiced at most Tabernacle Gatherings and illustrate how OSC negotiates crafting new traditions by fusing together elements from Christianity, Islam, and AIR. The first ritual is known as Yemaya Wudu. Yemaya refers to a Yoruba orisha that is the mother of all orishas in the Yoruba pantheon. She is known for her powers of intercession, fertility, healing, and is often associated with bodies of water. $W u d u$, on the other hand, refers to the Islamic practice of washing in preparation for prayer and worship. Within this ritual, there are two stations - one for males and one for females. Each station is uniform in style and size and features a low wooden table, approximately one meter off the floor. On top of each table is a large clay basin filled with water, as well as herbs and flowers from the garden. The concoction is prepared by a Babalawo (AIR priest) before each Tabernacle Gathering. Smaller bowls are provided for accessing the water and towels are provided in order to dry off afterward. Volunteers stand next to the stations and offer advice about the ritual. They hand the small bowls to each person and instruct them to 'baptise' themselves and 'pray to Yemaya for a blessing from the Holy Spirit'. The instructions for washing are vague and this results in varied practices. Some people scrub their hands, arms, feet, and face vigorously, while others lightly pour water over these areas. Some stand and others kneel. Some merely wash their hands or face. Some do the sign of the cross as they perform the ritual. Some stand and dance and others fall prostrate on the ground. In conversation with members of OSC, it is apparent that this 
ritual evokes a variety of interpretations. At a July 2012 service, the following members briefly explained its purpose to me:

Chibueze: 'I take the water and wash, to wash away impurities. The water is of God and I feel refreshed afterward ... I think like repentance we need to do this every week to become clean again' ${ }^{46}$

Olayinka: 'Water is vital and sacred; used for purifying and healing. Yemaya is able to call upon the Holy Spirit for us. The Goddess blesses us when we do this'. ${ }^{47}$

Funanya: 'This is simple because water washes away not only dirt, but more than this. This water symbolises God's purity ... we wash with it to participate in this purity and Yemaya is part of helping us in this'. ${ }^{48}$

The second ritual ceremony, known as Chrislamic Divination, offers a similar creative fusion. While again, performance varies, a Babalawo is invited to perform a corporate divination in front of the congregation. While OSC asked me not to document the ritual out of fear that it might bring a curse, I can say that the Babalawo uses palm nuts and an opele (Ifá divination chain) during the ceremony and he always recites from the Odì Ifá. During the divination, the Babalawo invokes Jesus, Muhammad, and the God of the Universe to assist with the ritual. At the same time, it is common for members to perform the sign of the cross, fall prostrate, and even perform the Islamic salat. Depending on the result of the divination, the Babalawo suggests appropriate offerings or changes and disciplines that the congregation needs to undertake. During the same July 2012 service, I asked one of the members of OSC, Shola, to provide an explanation of Chrislamic Divination and how it fits into the life of OSC. Shola stated: 'Chrislam is basically just a combination of ways to get in touch with God and with our ancestors. The Chrislamic Divination calls upon multiple sources of authority to accomplish this task ... what outsiders may see as different or even contradictory traditions, we see continuity and uniformity.' 49

\section{THE PUBLIC RECEPTION OF CHRISLAM}

Despite their belief that they have received a divine call to counter the rise of divisive religious politics and violence, exemplified in their minds by movements such as Boko Haram, OSC has received substantial criticism and what they term 'religious persecution' at the hands of the local Ogbomoso population. Instances of social pressure, vandalism, and violence have led many within OSC to surreptitiously guard aspects of their religious entanglements in certain contexts. The following section presents a selection of conversations I had with OSC members regarding how they negotiate multiple religious belongings and identities in the midst of a legitimate fear of being marginalised at the hands of the wider public. It includes accounts from Ayokunle, Monifa, Bolaji, Opeyemi, Tula, Romoluwa, Jimoh, and Grace. 
By early 2006, OSC was growing quickly, but at the same time this made the group more vulnerable. One of the founders, Ayokunle, provided the following perspective:

In our first year, I believe God gave us protection. We had no attacks or anything upon our group. God knew that we needed this. We might have disbanded, you know, without this peaceful year. But as we grew stronger in our faith, so too did our responsibilities grow ... We were first attacked with threats, you understand? ... one of the people we had invited into our group did not like what we were doing. Upon our next meeting, she brought others from her church to debate with us. We were welcome to the debate and we discussed many things, but when they found us resolute in our convictions, they claimed that God would strike us down for our heretical beliefs ... they told us that we were creating an evil religion from good religions and that we were upsetting the balance for the Yoruba people..$^{50}$

While this threat did not immediately result in any physical conflicts, members started to question their security and the 'persecution' intensified. As one member, Monifa, recalled:

We are persecuted because of our religion. We believe there is only one religion. Islam, Christianity, Traditional religions, these are all the same. Others in Ogbomoso do not believe this is right. So, they threaten us. Threaten to kill us or imprison us. They call us heretics. They say we are destroying Nigeria ... they have destroyed our property ... [they] send youths to vandalise ... I know of many who have been put in prison. ${ }^{51}$

While the reference to unlawful imprisonments may be embellished, I did find one member who claims to have been beaten and put into prison briefly for his affiliation with OSC. Bolaji described to me how in 2009, his former neighbour, a police officer, discovered he was part of OSC. As Bolaji recalled:

This man, my neighbour was very unhappy with me because he found out that I was part of the 'evil Chrislam religion' ... he said I was part of a cult, the Chrislamic cult ... he claimed what I was doing was illegal and that he would personally shut us down. He would not let me speak or defend myself. Instead, he phoned other officers and they beat me and took me into prison ... [I] was there for two days ... They did not give me any food or water ... I was told to never go back and they let me go. ${ }^{52}$

Claims of vandalism have also become a regular feature in the life of OSC members. Opeyemi, a member since 2007, informed me of one of these occasions: 'My family came for a Tabernacle Gathering ... youths had painted with black over our doors and signs. We no longer keep our sign up during the week. Too many times this has happened'. ${ }^{53}$ In another case from 2007, OSC claims that the building they were meeting in at the time was maliciously burned to the ground. The property owner, Tula, also an OSC member, recounted the events: 
Yes, I owned that property. It was a small dirt building, not a nice building ... we were forced to move there until we could find a better place. But we were there for maybe two, maybe three months. There were some people in the community, those surrounding it [the building], that became very suspicious of us. They went to the police to shut us out, to get us out because they thought we were part of some terrible cult... the police came but did nothing. Some days later, in the night, youths came and destroyed it. They burned it, set it on fire ... I went to them [the police], but they did nothing. Nothing. Can you imagine? They would not even report it. No paperwork. They told me to go away, get out old man. ${ }^{54}$

Beyond stories of unlawful imprisonment, vandalism, and arson, other specific claims of persecution include physical abuse, verbal abuse, familial excommunication, social excommunication, bribery, and job loss. One OSC member, Romoluwa, revealed how she has experienced such marginalisation:

My story is very bad. My family are Muslims. Someone told them that I was part of this blaspheming cult ... [because] we include Christianity and Traditional religion in our beliefs and this is said to be evil ... my father forbade me from ever going back ... they found out that I was still going and my father beat me. He yelled at me and cursed me ... he would not let me leave my home. He beat me many times ... [he] broke my wrist and my eyes were sealed shut. I left secretly and now live with friends. I have been excommunicated from my family and many friends. I had to leave my job because I worked for my uncle ... I am still angry at them all ... [I feel] abandoned, but I know God is with me..$^{55}$

Relatedly, stories of bribery are common among those who reveal their affiliation with OSC to family members. As one OSC member, Jimoh, revealed:

[Once my father found out that I went to OSC] he offered me bribes to come back to Christianity. I told him I hadn't left Christianity, but he wouldn't listen. [The bribes included] money usually, or jobs. Even cars and okadas [motorised bikes]... he would even leave money on my desk ... to tempt me ... to reverse my beliefs ... There is [still] respect [between us], but there is also this distance between us and our family never speaks about it ... certainly my father has not told his brothers or other family ... one of his brothers is a pastor. He would not be happy with me if he found out. ${ }^{56}$

While Jimoh's belonging to OSC has caused some level of tension with his family, he has not been willing to reveal this information with many of his family and friends. Indeed, many times, rather than being an open topic of conversation, even when such conflict emerges, it remains hidden within families and tight social networks. This makes these phenomena difficult to track and uncover.

Those who do reveal their belonging to OSC openly are highly likely to be marginalised in some way. My conversations with group members revealed that some individuals had left OSC as a result of this fear. It is difficult to know how many, but 
it appears between 15-25 individuals have left the group for this reason. While working on a separate case study, I came across one individual, Grace, who claimed to have been part of the group in 2010, but left when she became fearful and paranoid. Grace was hesitant to discuss this initially. I met her at a Baptist church while conducting interviews with people who had converted from Islam to Christianity. She was curious about my project and I gave her my contact information. She called me months later and said she would like to discuss an issue related to Chrislam. It was an informal conversation, so I did not record it, but she revealed that she lived in constant fear while she was attending services at OSC. She said that she became paranoid and thought that members of her church and police officers were targeting her. She feared for her life, so she broke off her connection and has not been back as a result. Despite retaining a private religious identity that draws upon multiple traditions, Grace found that in her case a publicly revealed belonging to OSC had social-psychological consequences. ${ }^{57}$

Alongside these direct investigations of how OSC members have been negatively impacted by their affiliation with the group, I have also interviewed a range of religious leaders in Ogbomoso about the Chrislam movement in general. These interviews were quite revealing, as they often spoke of Chrislam in rather apocalyptic terms. As a Baptist minister named Ado quipped: 'The problem with these Chrislam people is that they have a ... cavalier attitude ... they do not care about the consequences of their actions and these will surely be catastrophic. ${ }^{58}$ Another Pentecostal pastor named Jonathan told me: 'Chrislam is a truly evil religion. What is so bad is that it takes respectable, good religions and it makes a mess of them ... I wouldn't be surprised if God struck the Chrislam cult down and wiped it away from this planet because of what they are doing. ${ }^{59}$ A local imam named Abdullah spoke about Chrislam in similar terms: 'Chrislam is so ignorant that it has become evil ... those Chrislam people are going to start a war here in Nigeria ... Chrislam could be the death of this country. ${ }^{60}$

\section{CHRISLAM AND THE POLITICS OF RELIGIOUS BRICOLAGE}

It is little wonder that Chrislam began in a megacity such as Lagos, now the largest city in Africa, where the local turn of phrase is 'anything is possible'. It is also unsurprising that Chrislam has spread to Yoruba cities such as Ogbomoso, which sits at the intersection of a historical triangle of religious convergence. Just to the southeast of Obgomoso sits the town of Ifè, the cradle of Yoruba civilisation and spiritual centre of Yoruba AIR. To the west is the country of Benin, one of the very few countries in the world that continues to primarily identify with AIR; an influence that spills over the border into nearby places like Ogbomoso. Just a short way up the road to the northeast sits the city of Ilorin, the former edge of the Sokoto Caliphate, a once expansive and powerful Islamic empire. While the power of the Caliphate drastically waned with British colonisation in the twentieth century, Islam became thoroughly integrated in its territories. Finally, in the south, all the way from the coast to Ogbomoso's doorstep, the impact of foreign and indigenous mission efforts is 
apparent, with some of the largest and most influential Christian groups in Africa dotting the landscape. Many refer to this area as the future Jerusalem and there are modern day prophecies about this area being the new cradle of Christendom.

Given this competitive multireligious milieu, everyday interreligious encounters in this part of Nigeria are the default and produce what Marloes Janson and Birgit Meyer term a "religious field" in which several religious groups coexist in ever shifting dynamics of similarity and difference'. ${ }^{61}$ In the case of OSC, however, their framework of accommodation intends to take the interreligious encounter beyond coexistence. Within the confines of the group, this results in Christianity, Islam, and AIR being fused and embedded in their belief structures, liturgical practices, and ritual ceremonies. With their focus on pursuing unity and commonality while dispelling differences, OSC manages to creatively navigate, appropriate, and reconstruct multiple complex religious traditions, in what can be described as a religious bricolage. With origins in artistic 'tinkering' to construct makeshift handiwork, bricolage is now used in a wide number of fields to describe a construction or reconstruction made of whatever materials are at hand. In this case, the religions of Nigeria are readily at hand for OSC. Relatedly, the bricoleur is the constructor. In this case, the founders of OSC were initially the bricoleurs, but now other active members of OSC contribute. Within cultural studies, French anthropologist and ethnologist Claude Lévi-Strauss was the first to use the term in his 1962 work, La Pensée Sauvage. ${ }^{62}$ In describing mythical cultural patterns, LéviStrauss distinguished between the work of the bricoleur, which is makeshift, and the work of the ingénieur (engineer), which is precise and calculated. This distinction and terminology is highly applicable to OSC, which at less than fifteen years old is still very much in the makeshift phase. At the same time, however, there are limitations to using bricolage and bricoleurs for an analytical framework. As Jacques Derrida points out, 'If one calls bricolage the necessity of borrowing one's concept from the text of a heritage which is more or less coherent or ruined, it must be said that every discourse is bricoleur [and every bricolage is discourse]'. ${ }^{63}$ Relating this discussion to the description of religious groups and movements, bricoleurs constructing bricolages can be argued as commonplace. Yet, even so, there are undoubtedly varying degrees of bricolage and OSC undoubtedly fits into a pattern of exceptionality. Relatedly, as OSC further institutionalises, the terms bricolage and bricoleurs may no longer apply, as the process might turn the bricoleurs into ingénieurs.

While OSC's accommodating approach offers a contrast to the violent tendencies of movements such as Boko Haram, most people I spoke to about Chrislam in Ogbomoso are convinced that the resulting religious bricolage is at the very least offensive and perhaps even dangerous. In terms of the rhetoric employed by OSC's critics, this ranges from saying that Chrislam members have a cavalier attitude to tradition, to more apocalyptic descriptions such as Chrislam is likely to cause a cataclysmic disaster because it is an evil cult. It is clear that the perception for many is that OSC's intention to conflate multiple religions into a single religious movement threatens the relatively stable boundaries between and interaction among different religious traditions in southwest Nigeria. Relatedly, led by the founder's received 
vision, OSC has been brutal in their critiques of religion, as they perceive it to be practiced by most Nigerians. This has not won them many admirers. While these explanations do not justify the range of harmful and violent responses to the group, it does provide a better contextual understanding for Chrislam's public reception.

\section{CONCLUSION}

The Yoruba in southwest Nigeria are famous for their relaxed, peaceful, and accommodating approach to religious belonging and identity. J. D. Y. Peel has described this phenomenon as 'the religiously-unmarked cultural repertoire of the Yoruba'. ${ }^{64}$ The cultural foundation of which is provided by AIR such as Ifá, which as Peel has also noted, offers a ' ... pragmatic and client-centered system of oracular consultation, and not a congregational religion ... [instead it works] ... in practice to embrace a multitude of individual perspectives (albeit within a common framework of cosmology and ritual practice) rather than impose any kind of collective ideology' ${ }^{65}$ However, with the influx of more divisive forms of Christianity and Islam, which are increasingly rooted in aggressive conversionary practices and exclusivist claims, the politics of religious bricolage are heating up and the ability of AIR to domesticate this division is being tested. Indeed, OSC finds itself at the centre of an on-going public debate regarding the limits of Yoruba accommodation. While religious entanglements are common in Ogbomoso, these are often relegated to the private, individual realm, or superficially stripped of their overt religious significance in order to enter the sphere of accepted community culture. ${ }^{66}$ As well, the mixing of AIR with either Christianity or Islam remains moderately acceptable, while the mixing of Christianity and Islam is strongly rejected by most Nigerians. OSC's conspicuous bricolage of Christianity, Islam, and AIR, and the resulting public fallout, demonstrates that AIR can only domesticate Christianity and Islam to a point, and that even the famously accommodating Yoruba place limits on the types and forms of acceptable religious entanglements.

Corey L. Williams is Assistant Professor of Anthropology and Global Christianity at Leiden University, The Netherlands. He also serves as the General Secretary for the African Association for the Study of Religions and Co-Chair of the World Christianity Unit for the American Academy of Religion. Email: c.1.williams@hum.leidenuniv.nl

\footnotetext{
${ }^{1}$ Gilbert K. Chesterton, The Flying Inn (New York: John Lane Company, 1914), 45.

${ }^{2}$ Arthur C. Clarke, 'The Hammer of God: A New Story', Time Magazine 140.9 (Fall 1992): 83-87. Clarke adapted parts of this story to become a novel, released the following year as: Arthur C. Clarke, The Hammer of God (New York: Bantam Books, 1993).

${ }^{3}$ Clarke, 'The Hammer of God', 84.

${ }^{4}$ While there are numerous alternatives for referring to the indigenous religions of Africa, I opt to use the term 'African Indigenous Religions', which I consider to have four primary benefits: (1) it insists parity with other religions by being a proper noun; (2) it is plural which encourages a heterogeneous understanding; (3) it is generally considered innocuous, whereas terms such as 'African Traditional Religion' have merely shifted crude tropes like paganism, primitivism, primal, and unmodern to the
} 
term 'traditional'; and (4) it highlights that these religions are indigenous to Africa-as in these are religions that originated in Africa. While Christianity and Islam have certainly 'indigenized' in Africa, these religions did not originate on the African continent. It is recognized that these benefits do not eliminate all of the problems associated with the term. For instance, while it is often assumed that AIR are homogenous, as Afe Adogame points out, AIR are highly diverse and is 'often shaped by particular ethnic groups, power structures and even the characteristics of natural phenomenon in each locality.' See: Afe Adogame, 'How God Became Nigerian: Religious Impulse and the Unfolding of a Nation', Journal of Contemporary African Studies 28.4 (2010), 480. For further discussion, see also:

James L. Cox, From Primitive to Indigenous: The Academic Study of Indigenous Religions (New York: Routledge, 2016), 9-74.

${ }^{5}$ This study is based upon 12 months of fieldwork and archival research conducted in 2011-2012, as well as short-term field visits in 2017 and 2018. In addition to long-term participant observation, I also conducted qualitative research interviews, focus group interviews, and two demographic surveys.

${ }^{6}$ Bishop Neill's Travel Diary, Entry No. IX (28 May 1950), 6. The diary has been transcribed and is available within the archives of the Centre for the Study of World Christianity at the University of Edinburgh, UK.

${ }^{7}$ Ibid.

${ }^{8}$ Ibid.

${ }^{9}$ For more on the Holy Aruosa Cathedral, see: Flora Edouwaye S. Kaplan, 'Understanding Sacrifice and Sanctity in Benin Indigenous Religion, Nigeria: A Case Study', in Beyond Primitivism: Indigenous Religious Traditions and Modernity, ed. Jacob K. Olupona (New York: Routledge, 2004), 185-194. See also: Wilson E. Ehianu, 'Holy Aruosa Cathedral in Benin: Historical and Phenomenological Perspectives', ORITA 42.1 (2010), 51-65.

${ }^{10}$ For academic research on Ifeoluwa, see: Marloes Janson and Mustapha Bello, 'Chrislam: Forging Ties in Nigeria's Multi-Religious Society', in New face of Islam in Eastern Nigeria and the Lake Chad Basin, ed. Egodi Uchendu (Makurdi: Aboki Publishers, 2012). See also: Marloes Janson, 'Unity Through Diversity: A Case Study on Chrislam in Lagos', Africa 86.4 (2016): 646-672.

11 There are at least 80 rules and regulations related to behavior, morality, discipline, dress, food taboos, and hygiene.

${ }^{12}$ Adeboye has written a book to assist this expansion. See: Hazzan-Odede Adeboye, The Last Trumpet (Lagos: Foffi Publishers, 2009).

${ }^{13}$ Tella claims that Saka stole the idea of 'Chrislam' from him, but Tella maintains that he began his group without knowledge of Tella's group. Despite all advocating the benefits of Chrislam, these groups do not interact with one another.

${ }^{14}$ Kehinde Emmanuel Obasola, 'Religious Syncretism in Oke Tude in South Western Nigeria', (Unpublished PhD Thesis, University of Ibadan, 2007), 54. Saka's revelation was also corroborated by others including Alhaji Bashir. As Obasola remarks, 'As a way of confirming this divine revelation, the same message was revealed to Alhaji Bashir who was also on pilgrimage to Mecca in a dream. He corroborated the views expressed by Dr Saka to be the pioneer of a new religion for the promotion of religious interaction in Nigeria and also for the emancipation of man from the bondage of oppression and diseases' (57).

${ }^{15}$ Ibid., 55. This group was also previously called the Chrislamherb Society. For more on this early form of the group, see: I. Aliyo, 'Chrislamherb: Experiment in Religious Harmony', Aura magazine, 13 May 1991, 11.

16 Obasola 59.

${ }^{17}$ Ibid., 59. While Saka does not facilitate AIR medicine and herbalism any longer, he does not preach against its use.

18 Janson and Bello 203. As Janson and Bello note, the Nigerian government refused to register the name Chrislamherb, however, with the name change to Oke Tude, the group was officially registered. See also: Obasola 18. Obasola states: 'Oke Tude simply means the Mountain of loosening bonds or the Mountain where fetters are disconnected'. The group has also been called 'The True Message of God Mission'.

${ }^{19}$ Beyond the article published by Janson and Bello and the unpublished $\mathrm{PhD}$ thesis by Obasola, the existent resources are scant. PBS has produced a six-minute segment on Oke Tude. See: Fred de Sam Lazaro, 'Chrislam', PBS: Religion and Ethics Newsweekly, 13 February 2009, http://www.pbs.org/wnet/religionandethics/ 2009/02/13/february-13-2009-chrislam/2236/ (accessed 1 November 2018). See also: Abraham McLaughlin, 'In Africa, Islam and Christianity Are Growing and Blending, The Christian Science Monitor, 26 January 2006, http://www.csmonitor.com/2006/0126/p01s04-woaf.html (accessed 1 November 2018). 
${ }^{20}$ Obasola 2.

${ }^{21}$ Janson and Bello 210.

${ }^{22}$ Obasola 58. This figure has not been carefully verified.

${ }^{23}$ I define active here as attending OSC events at least once per month. The attendance directory is a record of all the people who have ever attended an OSC event.

${ }^{24}$ The survey received 137 responses from active members making it highly representative of OSC.

${ }^{25}$ United Nations Department of Economic and Social Affairs/Population Division, World Population

Prospects: The 2012 Revision (New York: United Nations, 13 June 2013), 25. Based upon Nigeria's most recent census in 2006, the estimate for the population under the age of 35 was 77.45 percent. For more information, see: National Population Commission, '2006 Population and Housing Census of the Federal Republic of Nigeria' (Abuja: National Population Commission, 2006).

26 'Statistical Data Portal: Socio-Economic Data, Human Development, Percentage Distribution of Persons, Post-Secondary, Oyo State, 2009,' National Bureau of Statistics, http://www.nigerianstat.gov.ng (accessed 1 November 2018).

27 'Statistical Data Portal,' http://www.nigerianstat.gov.ng (accessed 1 November 2018).

${ }^{28}$ The founders requested that their surnames not be used in any publications. Additionally, due to safety and ethical concerns, pseudonyms have been assigned for all of my other interlocutors.

${ }^{29}$ Ọbáfẹmi. Interviewed by Corey Williams. Focus group interview. Ogbomoso, Nigeria, 22 October 2011.

${ }^{30}$ Ibukunoluwa. Interviewed by Corey Williams. Focus group interview. Ogbomoso, Nigeria, 22 October 2011.

${ }^{31}$ Another common translation I heard in Nigeria is: 'When a leaf used to wrap soap remains long enough with it, it turns to soap'.

32 J.D.Y. Peel, Religious Encounter and the Making of the Yorùbá (Bloomington, IN: Indiana University Press, 2003), 248.

${ }^{33}$ Obáfẹmi. Interviewed by Corey Williams. Focus group interview. Ogbomoso, Nigeria, 7 July 2012.

${ }^{34}$ Ayokunle. Interviewed by Corey Williams. Focus group interview. Ogbomoso, Nigeria, 7 July 2012.

${ }^{35}$ Ọbáfẹmi. Interviewed by Corey Williams. Focus group interview. Ogbomoso, Nigeria, 7 July 2012.

${ }^{36}$ Oluwaseun. Interviewed by Corey Williams. Individual interview. Lagos, Nigeria, 21 July 2018.

${ }^{37}$ Ibukunoluwa. Interviewed by Corey Williams. Individual interview. Lagos, Nigeria, 21 July 2018.

${ }^{38}$ Olafunke. Interviewed by Corey Williams. Individual interview. Ogbomoso, Nigeria, 14 July 2012.

${ }^{39}$ Ishola. Interviewed by Corey Williams. Individual interview. Ogbomoso, Nigeria, 14 July 2012.

${ }^{40}$ Fieldnote Entry. Recorded by Corey Williams. Ogbomoso, Nigeria, 11 November 2011.

${ }^{41}$ Fieldnote Entry. Recorded by Corey Williams. Ogbomoso, Nigeria, 7 July 2012.

42 Ositadimma. Interviewed by Corey Williams. Individual interview. Ogbomoso, Nigeria, 3 February 2012.

${ }^{43}$ Fieldnote Entry. Recorded by Corey Williams. Ogbomoso, Nigeria, 7 July 2012.

${ }^{44}$ Fieldnote Entry. Recorded by Corey Williams. Ogbomoso, Nigeria, 28 January 2012.

${ }^{45}$ Fieldnote Entry. Recorded by Corey Williams. Ogbomoso, Nigeria, 7 July 2012.

${ }^{46}$ Chibueze. Interviewed by Corey Williams. Format: Focus group interview. Ogbomoso, Nigeria, 7 July 2012.

${ }^{47}$ Olayinka. Interviewed by Corey Williams. Focus group interview. Ogbomoso, Nigeria, 7 July 2012.

${ }^{48}$ Funanya. Interviewed by Corey Williams. Focus group interview. Ogbomoso, Nigeria, 7 July 2012.

${ }^{49}$ Shola. Interviewed by Corey Williams. Focus group interview. Ogbomoso, Nigeria, 7 July 2012.

${ }^{50}$ Ayokunle. Interviewed by Corey Williams. Individual interview. Ogbomoso, Nigeria, 28 June 2013.

${ }^{51}$ Monifa. Interviewed by Corey Williams. Individual interview. Ogbomoso, Nigeria, 5 January 2013.

${ }^{52}$ Bolaji. Interviewed by Corey Williams. Individual interview. Ogbomoso, Nigeria, 22 January 2013.

${ }^{53}$ Opeyemi. Interviewed by Corey Williams. Individual interview. Ogbomoso, Nigeria, 24 January 2013.

${ }^{54}$ Tula. Interviewed by Corey Williams. Individual interview. Ogbomoso, Nigeria, 3 February 2013.

${ }^{55}$ Romoluwa. Interviewed by Corey Williams. Individual interview. Ogbomoso, Nigeria, 16 January 2013.

${ }^{56}$ Jimoh. Interviewed by Corey Williams. Individual interview. Ogbomoso, Nigeria, 8 March 2013.

${ }^{57}$ Fieldnote Entry. Recorded by Corey Williams. Ogbomoso, Nigeria, 4 October 2011.

${ }^{58}$ Ado. Interviewed by Corey Williams. Individual interview. Ogbomoso, Nigeria, 5 November 2011.

${ }^{59}$ Jonathan. Interviewed by Corey Williams. Individual interview. Ogbomoso, Nigeria, 10 November 2011.

${ }^{60}$ Abdullah. Interviewed by Corey Williams. Individual interview. Ogbomoso, Nigeria, 9 October 2011. 
${ }^{61}$ Marloes Janson and Birgit Meyer, 'Introduction: Towards a Framework for the Study of ChristianMuslim Encounters in Africa', Africa 86.4 (2016): 616.

${ }^{62}$ Claude Lévi-Strauss, La Pensée Sauvage (Paris: Librairie Plon, 1962).

${ }^{63}$ Jacques Derrida, Writing and Difference (Chicago: University of Chicago Press, 1978), 285.

${ }^{64}$ J. D. Y. Peel, 'Islam, Christianity and the Unfinished Making of the Yoruba.' Paper presented at the Mellon Foundation Sayer Seminar, University of Michigan, 1-2 April 2011.

${ }^{65}$ J.D.Y. Peel, Christianity, Islam, and Orisa-Religion: Three Traditions in Comparison and Interaction (Oakland, CA: University of California Press, 2016), 78.

${ }^{66}$ I make such observations in a forthcoming article: Corey L. Williams, 'Multiple Religious Belonging and Identity in Contemporary Nigeria: Methodological Reflections for World Christianity', manuscript submitted for publication. For another case of religious entanglements, see: Insa Nolte, Olukoya Ogen, and Rebecca Jones, eds., Beyond Religious Tolerance: Muslim, Christian, and Traditionalist Encounters in an African Town (Rochester, NY: James Currey, 2017). 